\title{
EVOLUTIONARY BIOLOGY AND BELIEFS HOW IDEOLOGY CAN DRAW DIFFERENT SOCIAL STANCES FROM SCIENCE
}

\author{
Michael RuSE
}

\begin{abstract}
Agreeing that there are often strong connections between fields of science and the ideological convictions of those producing the science, this essay shows that the connections are often complex and rarely straightforward. Taking the example of evolutionary biology, by looking at three key figures - Herbert Spencer, Charles Darwin and Alfred Russel Wallace - it is shown how very different social beliefs can lead to very different social conclusions being drawn from one's science. It is argued that this message should be kept firmly in mind by those who today would draw social conclusions from science, for instance suggesting that Darwinian evolutionary biology leads straight to the social philosophy of the Third Reich. The truth is always far more complex.
\end{abstract}

Keywords: social Darwinism, Herbert Spencer, Charles Darwin, Alfred Russel Wallace, Adolf Hitler.

That science can be used for ideological purposes is a commonplace. Obviously and notoriously, the Nazis used their versions of racial science to support the Third Reich (Harrington, 1999). But the same is true also in areas where one might find the ends more morally acceptable and the science of better quality. Think for instance of the ways in which gender studies have been used to promote female equality and, more recently, homosexual rights (LeVay, 2010). Does anyone think that, almost overnight, America would have come to accept the legitimacy of gay marriage, were it not for the work of sexologists from Sigmund Freud through Alfred Kinsey and on down to today's researchers? Of course, one needs to put the science in context. Gay and lesbian activists were crucial factors in our change in mind (and law) about the social moves, but without the science one much doubts that anything very much would have happened.

Nevertheless, there is a strong feeling - especially among scientists themselves but also supported by more traditionally minded philosophers of science that the science itself is, or should be, non-ideological. Drawing the traditional distinction between fact and value, the feeling is that science attempts to «tell it as it is». It is small wonder that the philosopher of choice is the late Sir Karl Popper (1972). A strong defender of the objectivity of science he is famous for saying that: «Science is knowledge without a knower.» Of course he did not mean that there was no scientist involved in doing science, but rather that the identity of the scientist - male or female, black or white, gay or straight, Christian or atheist - does not (should not) get into the science itself. The notion of «Jewish science» or «feminist science» is an oxymoron, rather like «weapons for peace».

In the past half century, this view of science has come under fierce attack. There are various reasons, but not the least is the growth of the history of science as a discipline. As soon as students of the subject were trained professionally - for instance to go to the archives and look at the letters and notebooks and not to rest content with the published word - it became increasingly obvious that science is a very human activity and the hopes and aspirations of scientists themselves simply influenced the science they produced and, even where the ideologies were not prominent, the views of the scientists had the habit of entering into the finished product. Although whether what was in the science and what could be taken out of the science was always quite what the scientist involved intended is another matter. Apart 
from the fact that he or she might have had no conscious intentions whatsoever.

My own field of evolutionary studies illustrates strongly the point I am making. In the 1970s, there was major controversy over the new sub-discipline of sociobiology, the study of behavior (including human behavior) from a Darwinian perspective. On the one hand, there were enthusiasts like the Harvard ant-specialist Edward O. Wilson $(1975,1978)$ who argued that now one had a vital tool to understanding humankind, including gender roles, social organizations, and religious commitments. On the other hand, there were critics like Wilson's Harvard colleagues, the geneticist Richard Lewontin (1991) and the paleontologist Stephen Jay Gould (1981), who argued that human sociobiology was a vehicle for right-wing, sexist, capitalist propaganda wrapped up in the language of modern science. Probably there was truth (and untruth) in the claims of both sides (Segerstrale, 1986), although whether the last word has yet been said may be debated.

Here I want to take things back a century and more, to the early days of modern evolutionary thinking. There would probably be little disagreement that there was interfering ideology back then, because most people have heard the term social Darwinism and there would be wise nodding of the heads in agreement that evolutionary biology has long been a vehicle for a virulent form of laissez faire socioeconomics: «Widows and children to the wall and let the strongest survive». As it happens, like most scholars in the field, I prefer not to use the term social Darwinism. It was not generally in use in the nineteenth century when evolutionary theory blossomed and came into its own, and it covers a multitude of positions, not all of which are associated with the work of Charles Darwin (Ruse, 2016). Investigation shows that some of the supposedly most egregious cases of social Darwinism are not like the presumption at all (Bannister, 1979). No one could deny that some of the robber barons like John D. Rockefeller and Andrew Carnegie could be absolutely ruthless, but generally there was another side. Rockefeller spent a considerable amount of his fortune on the founding of the new university in Chicago - indeed he got the ball rolling with an initial pledge of 600,000 dollars. Carnegie, who broke the workers at his steelworks in the Homestead Strike, spent his considerable fortune on the founding of public libraries. These were places where the poor but gifted child could go and through the provision of free reading material, self-educate themselves in ways not possible before. To speak personally for a moment,

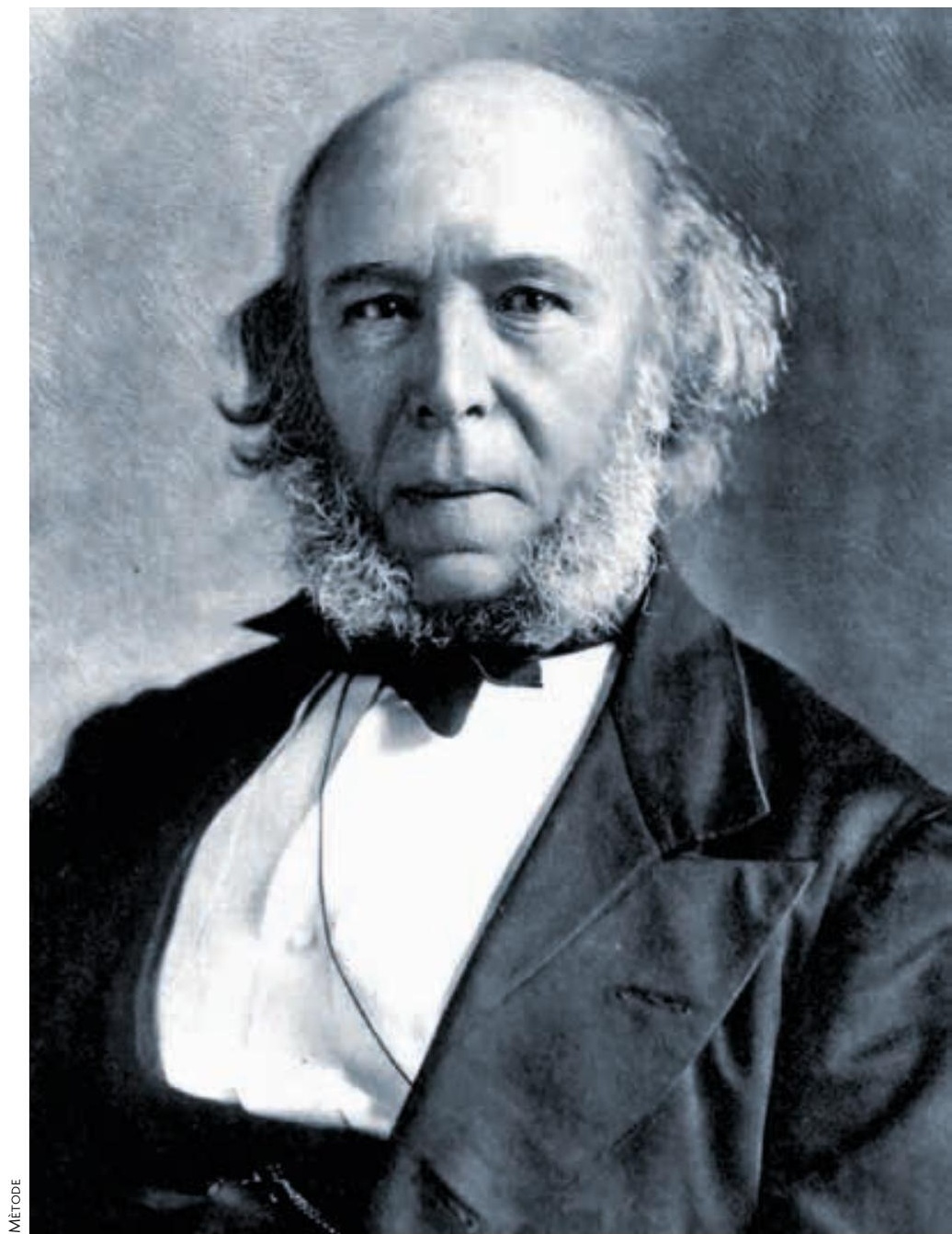

Herbert Spencer (1820-1903) trained as a surveyor but soon found his métier as a popular writer and universal thinker in journals and also in many books. He was indeed brought up to enthuse about laissez faire philosophies, and his first book, Social statics, reflects this.

some of my happiest memories as a child in England in the years after the Second World War are of long hours spent in a Carnegie library with my nose firmly in a book.

To get a proper understanding of how ideological commitments about social and economic policy got into evolutionary thinking, it is useful to highlight three early, key figures: Herbert Spencer, Charles Darwin, and Alfred Russel Wallace. Take them in turn.

\section{HERBERT SPENCER}

Herbert Spencer (1820-1903) trained as a surveyor but soon found his métier as a popular writer and universal thinker in the journals and also in many 
books. He was indeed brought up to enthuse about laissez faire philosophies, and his first book, Social statics, reflects this.

We must call those spurious philanthropists, who, to prevent present misery, would entail greater misery upon future generations. All defenders of a Poor Law must, however, be classed among such. That rigorous necessity which, when allowed to act on them, becomes so sharp a spur to the lazy and so strong a bridle to the random, these pauper's friends would repeal, because of the wailing it here and there produces. Blind to the fact that under the natural order of things, society is constantly excreting its unhealthy, imbecile, slow, vacillating, faithless members, these unthinking, though well-meaning, men advocate an interference which not only stops the purifying process but even increases the vitiation - absolutely encourages the multiplication of the reckless and incompetent by offering them an unfailing provision, and discourages the multiplication of the competent and provident by heightening the prospective difficulty of maintaining a family.

(Spencer, 1851, pp. 323-324) of the overall upwards progress that characterizes the whole world process: from the undifferentiated to the differentiated, or in his words from the homogeneous to the heterogeneous:

Now we propose in the first place to show, that this law of organic progress is the law of all progress. Whether it be in the development of the Earth, in the development of Life upon its surface, in the development of Society, of Government, of Manufactures, of Commerce, of Language, Literature, Science, Art, this same evolution of the simple into the complex, through successive differentiations, hold throughout. From the earliest traceable cosmical changes down to the latest results of civilization, we shall find that the transformation of the homogeneous into the heterogeneous, is that in which Progress essentially consists.

(Spencer, 1857, pp. 2-3)

Nothing escapes this law. Humans are more complex or heterogeneous than other animals; Europeans are more complex or heterogeneous than savages; and (hardly a surprise) the English language is more complex or heterogeneous than the languages of other speakers.

Spencer combined all of this with his views on the basis of ethics, arguing that morality emerges through the evolutionary process and our duties are to ensure that this happens by removing barriers and facilitating the process: «Ethics has for its subject-matter, that form which universal conduct assumes during the last stages of its evolution» (Spencer, 1879, p. 21). Continuing:

And there has followed the corollary that conduct gains ethical sanction in proportion as the activities, becoming less and less militant and more and more industrial, are such as do not necessitate mutual injury or hindrance, but consist with, and are furthered by, co-operation and mutual aid.

(Spencer, 1879, p. 21)

In other words, Spencer, who was deeply committed to an organic view of nature, saw conflict dropping away as humankind progressed ever higher. Carnegie in his funding of public libraries was being very Spencerian.

\section{CHARLES DARWIN}

Charles Darwin (1809-1882), the author of the On the origin of species (1859), was the father of the modern theory of evolution that sees natural selection goes to making brains or seeps out from your loins. Spencer saw organic evolution as being but one facet 
as the chief process of change. Like Spencer, he saw population pressures leading to a struggle for existence, in society as in the world as a whole. But then he went a different way.

Let it be borne in mind how infinitely complex and close-fitting are the mutual relations of all organic beings to each other and to their physical conditions of life. Can it, then, be thought improbable, seeing that variations useful to man have undoubtedly occurred, that other variations useful in some way to each being in the great and complex battle of life, should sometimes occur in the course of thousands of generations? If such do occur, can we doubt (remembering that many more individuals are born than can possibly survive) that individuals having any advantage, however slight, over others, would have the best chance of surviving and of procreating their kind? On the other hand, we may feel sure that any variation in the least degree injurious would be rigidly destroyed. This preservation of favourable variations and the rejection of injurious variations, I call Natural Selection.

(Darwin, 1859, pp. 80-81)

It is important to notice that, for Darwin, change is not random - it is always in the direction of what is known as «adaptive advantage». Does the feature being produced help its possessor? If it does, it might be selected. But not otherwise. This is the clue to Darwin's thinking about morality and how a society should be conceived and constituted. At one level, as a rich, upper-middle-class Englishman - his maternal grandfather and his wife's paternal grandfather was Josiah Wedgwood the potter- Darwin was all in favor of capitalism (Richards \& Ruse, 2016).

In all civilised countries man accumulates property and bequeaths it to his children. So that the children in the same country do not by any means start fair in the race for success. But this is far from an unmixed evil; for without the accumulation of capital the arts could not progress; and it is chiefly through their power that the civilised races have extended, and are now everywhere extending, their range, so as to take the place of the lower races.

(Darwin, 1871, p. 169)

Analogously, he had little time for unions. Writing to a German correspondent in 1872, Darwin said: «I much wish that you would sometimes take occasion to discuss an allied point, if it holds good on the continent, - namely the rule insisted on by all our Trades-Unions, that all workmen, - the good and bad, the strong and weak, $-\operatorname{sh}[$ oul] d all work for the same number of hours and receive the same wages.» Adding: «I fear that Cooperative Societies, which many look at as the main hope for the future, likewise exclude competition.

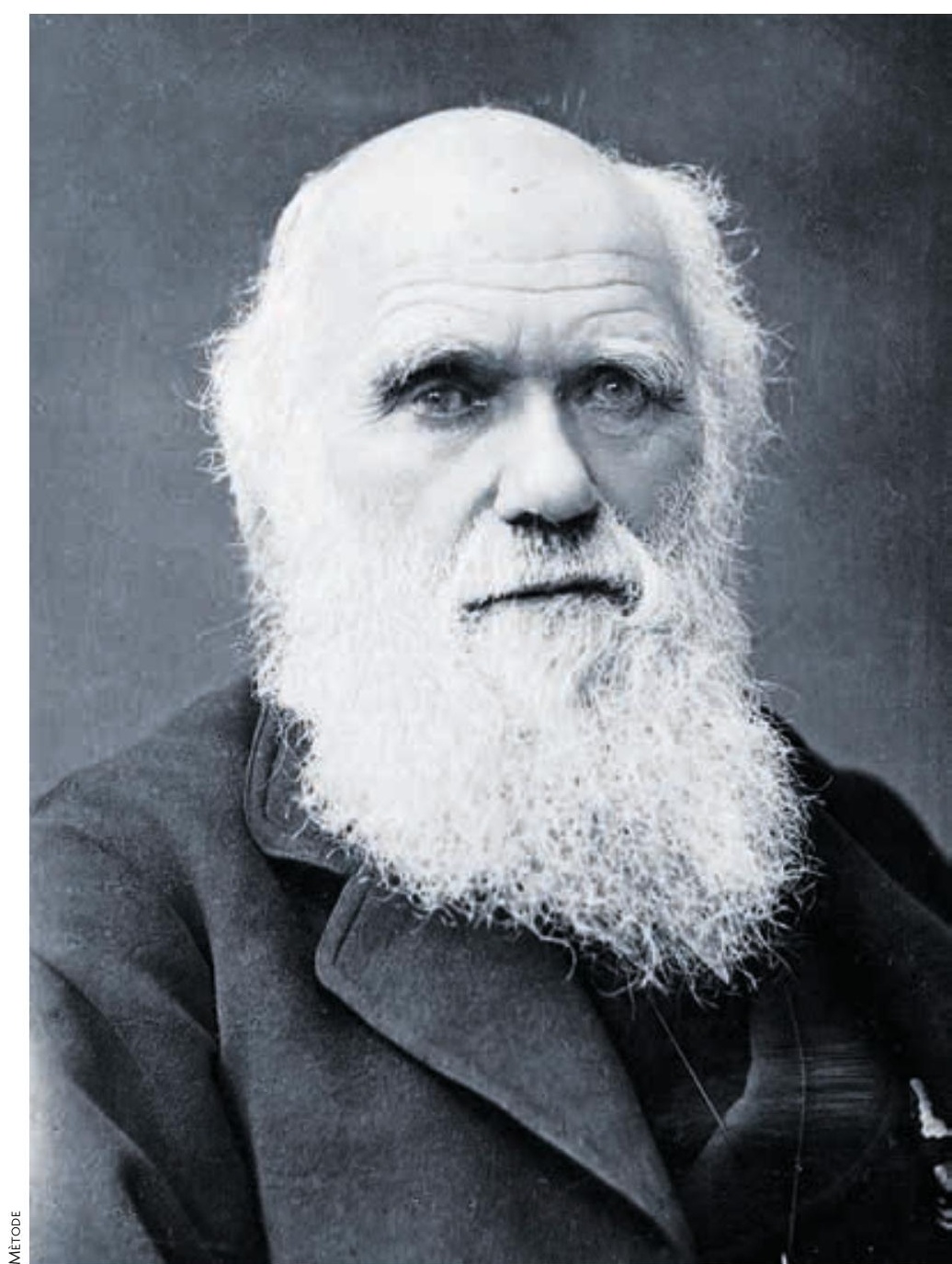

Charles Darwin (1809-1882), the author of On the origin of species (1859), was the father of the modern theory of evolution that sees natural selection as the chief process of change. Like Spencer, he saw population pressures leading to a struggle for existence, in society as in the world as a whole.

This seems to me a great evil for the future progress of mankind» (Darwin, 1985, vol. 20, p. 324).

But this said, Darwin was convinced that morality and working together in and for the good of society was not only in itself a good thing but something promoted by natural selection. Basically, together we succeed and separately we fail.

It must not be forgotten that although a high standard of morality gives but a slight or no advantage to each individual man and his children over the other men of the same tribe, yet that an advancement in the standard of morality and an increase in the number of well-endowed men will certainly give an immense advantage to one tribe over another.

(Darwin, 1871,p. 166) 


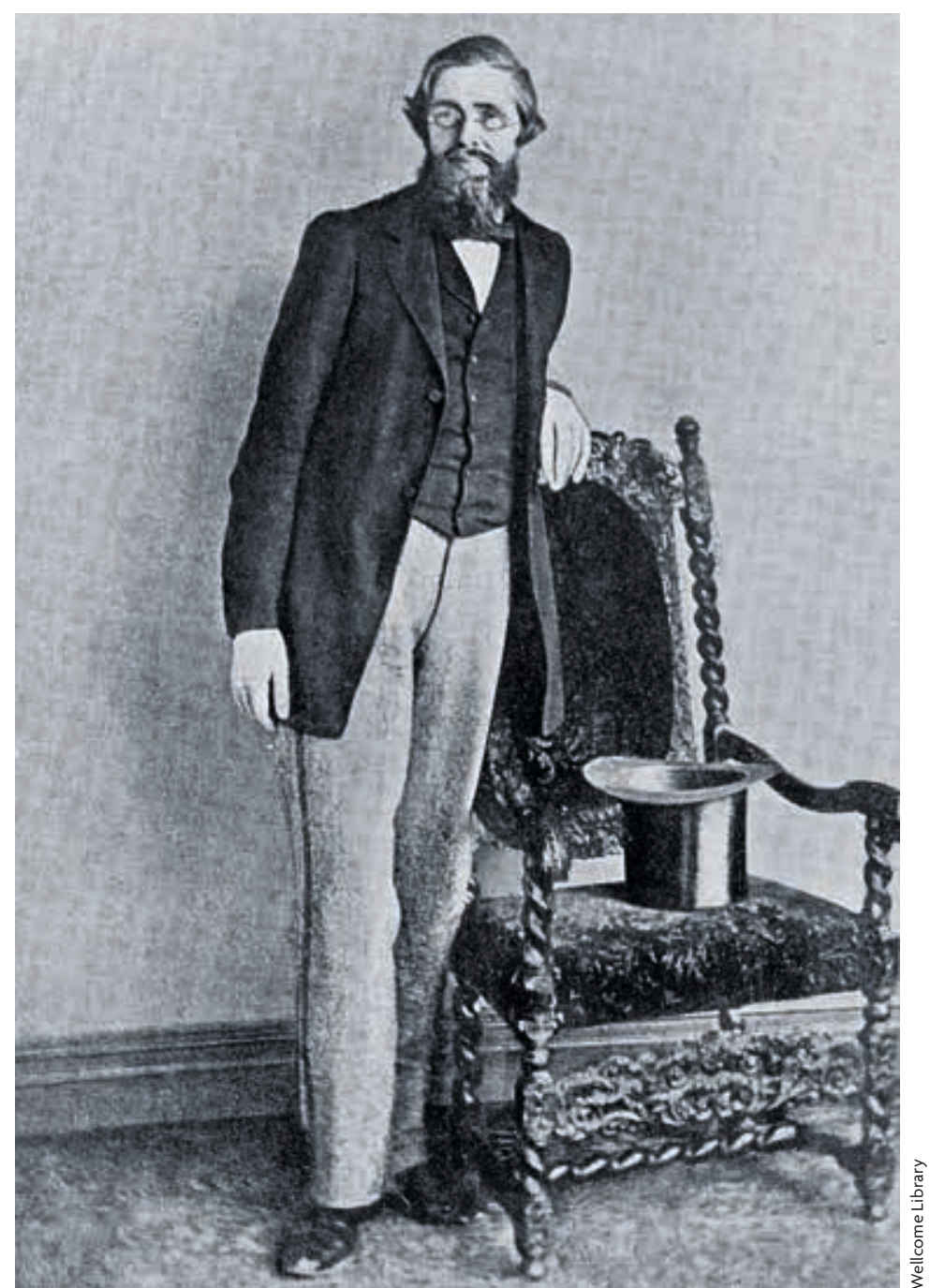

For Alfred R. Wallace (1823-1913), the struggle for existence was always between groups and adaptations were group phenomena. Darwin had to explain altruism in terms of enlightened selfinterest. Wallace thought that moral adaptations could always work against the individual so long as they benefited the group.

In other words, for Darwin no less than for Spencer, the evolutionary process is important in our socio-economic philosophies and we ignore evolution at our peril. But they have different positions and for neither is a simple laissez faire position the true or most central characterization.

\section{ALFRED RUSSEL WALLACE}

Alfred Russel Wallace (1823-1913), our third evolutionist, is as always particularly interesting. Like Spencer and Darwin he was from the British middleclasses, but he was from the very lowest level. He used to joke that his father had made such a mess of the family finances that he was immune from worry about the future because there was no further that he could fall (Wallace, 1905). Traveling in the Far East -finding specimens for rich collectors and museums Wallace hit upon the idea of natural selection, wrote up a short essay, and sent it to Darwin of all people (obviously word was out that Darwin was an evolutionist). A curious combination of brilliant scientist - his work on island biogeography was foundational - and naïve crank - he never deviated from a sincere belief in spiritualism - Wallace was ever a socialist. As an adolescent, he had heard the Scottish mill-owner Robert Owen, and that led to a lifetime commitment. For him, therefore, the struggle for existence was always between groups and adaptations were group phenomena. Darwin had to explain altruism in terms of enlightened self-interest. Wallace thought that moral adaptations could always work against the individual so long as they benefited the group.

Hitherto there has been no organisation of communities or of society at large for purposes of production, except so far as it has arisen incidentally in the interest of the capitalist employer and the monopolist land-owner. The result is the terrible social quagmire in which we now find ourselves. But it is certain that organisation in the interest of the producers, who constitute the bulk of the community, is possible; and as, under existing conditions, the millions who are wholly destitute of land or capital cannot organise themselves, it becomes the duty of the State, by means of the local authorities, to undertake this organisation; and if it is undertaken on the principle that all production is to be, in the first place, for consumption by the producers themselves, and only when the necessary wants of all are satisfied, for exchange in order to procure luxuries, such organisation cannot fail to be a success.

(Wallace, 1900, pp. 482-483)

With this - Wallace was nothing if not ecumenical about his enthusiasms - he endorsed a radical feminism, seeing society's future as one that depends exclusively on female choice. Writing at a time when the movement for women's suffrage was building steam, this was no disinterested position to endorse. One can only add wryly, as the parent of girls, that if Wallace's daughters actually chose only the bestquality young men with whom to breed, they must have been as atypical and odd as their father.

\section{IMPLICATIONS?}

Three evolutionists. Three very different perspectives on society and the ways to run it. There are many implications one can draw from this, but I want 
to conclude with one of if not the most important implication of them all. While it is undoubtedly true, that when people appeal to evolutionary theory for support of their ideological commitments, the thinking of the great nineteenth century evolutionists is relevant and important, one must be ever wary of seeing simple lines of connection between the past and the present. Take for example the question of the National Socialists, of Adolf Hitler in particular. The biblical literalists, the creationists and their newer milder but in-respects-more-dangerous offspring, the intelligent design theorists, tried first to show that evolutionary biology - Darwinian evolutionary biology in particular - is not good science (Whitcomb \& Morris, 1961). That failed,

so then they turned more philosophical, arguing that it fails methodologically and metaphysically (Johnson, 1995; Plantinga, 2011). That attack too came to naught, so now they are trying to tar it with the charge of immorality, basing their case on the supposed historical fact that nineteenth-century evolutionary theory led straight to the philosophy underlying the Third Reich (Weikart, 2004). And to be fair there is some prima facie evidence supporting their case. Consider the following passage from Mein Kampf.
All great cultures of the past perished only because the originally creative race died out from blood poisoning. The ultimate cause of such a decline was their forgetting that all culture depends on men and not conversely; hence that to preserve a certain culture the man who creates it must be preserved. This preservation is bound up with the rigid law of necessity and the right to victory of the best and stronger in this world.
Those who want to live, let them fight, and those who do not want to fight in this world of eternal struggle do not deserve to live.

(Hitler, 1925)

However, as always, things are a bit more complex than a first reading suggests. If you look at the supposedly Darwinian passages in context, you see that Hitler's real obsession is with racial purity, and this was certainly not Darwin's concern. As I just said, I would not want to argue that there are no links at all. Something had to lead to Hitler. But apart from the many other candidates - the music of Wagner, the anti-Semitism of Vienna when Hitler was a young man, the resentment over the Versailles Treaty, and more - what Hitler and his fellows were about was just not what Darwin and his fellows were about
(Richards, 2013). The evolutionists were concerned about personal and group morality, about the challenges of a world that was rapidly industrializing, and about how to move forward in a culture or society were belief in God was no longer universal and nowhere like as binding as it had been hitherto. The National Socialists were about group domination and uniformity and (as we know only too well) the domination and elimination of peoples who did not fit their mold or who were taken to be threats or barriers to German world-supremacy.

And of course there is also the fact that, as in the nineteenth century, one can always find someone using the same science for very different ends. Hitler was deeply committed to an organic view of the state - incidentally more Herbert Spencer than Charles Darwin. Julian Huxley, the biologist grandson of Darwin's great supporter Thomas Henry Huxley, had a very different take on things.

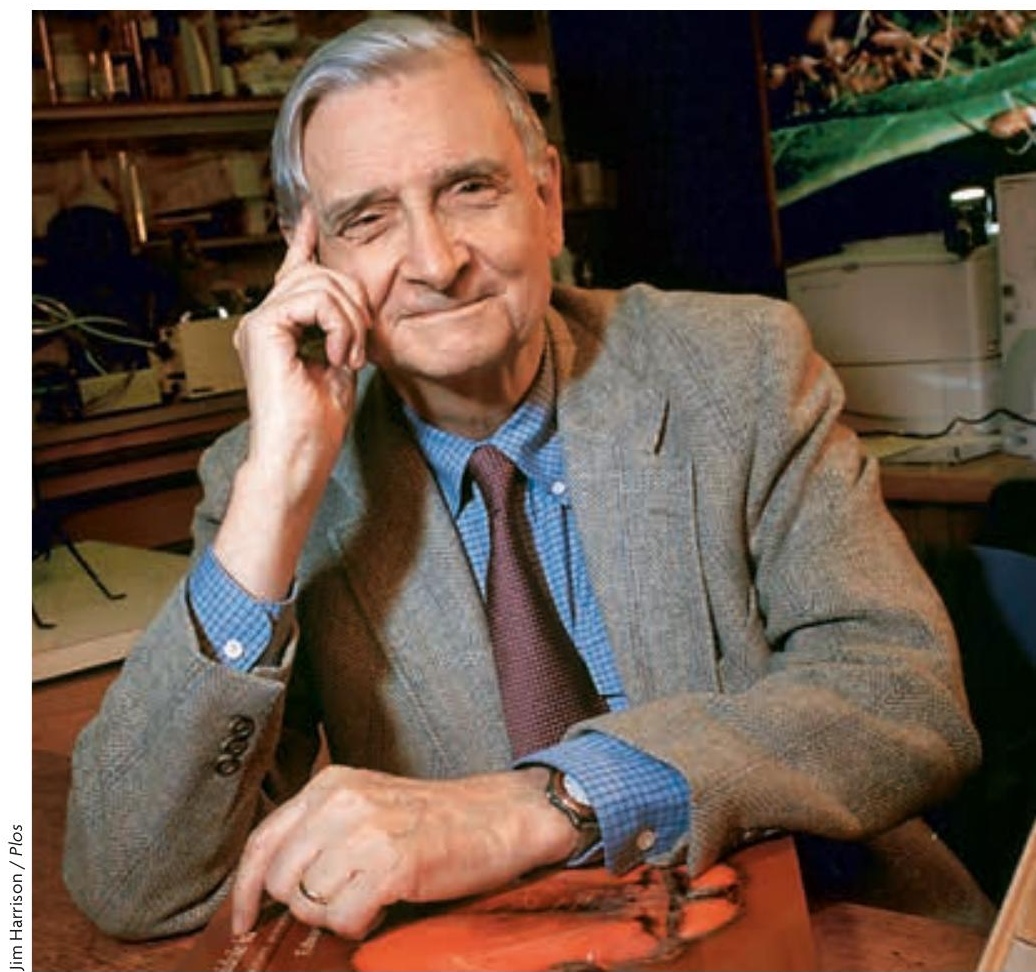

In the 1970s, there was major controversy over the new subdiscipline of sociobiology, the study of behavior (including human behavior) from a Darwinian perspective. There were enthusiasts like the Harvard ant-specialist Edward O. Wilson (in the photo) who argued that now one had a vital tool to understanding humankind, including gender roles, social organizations, and religious commitments. 


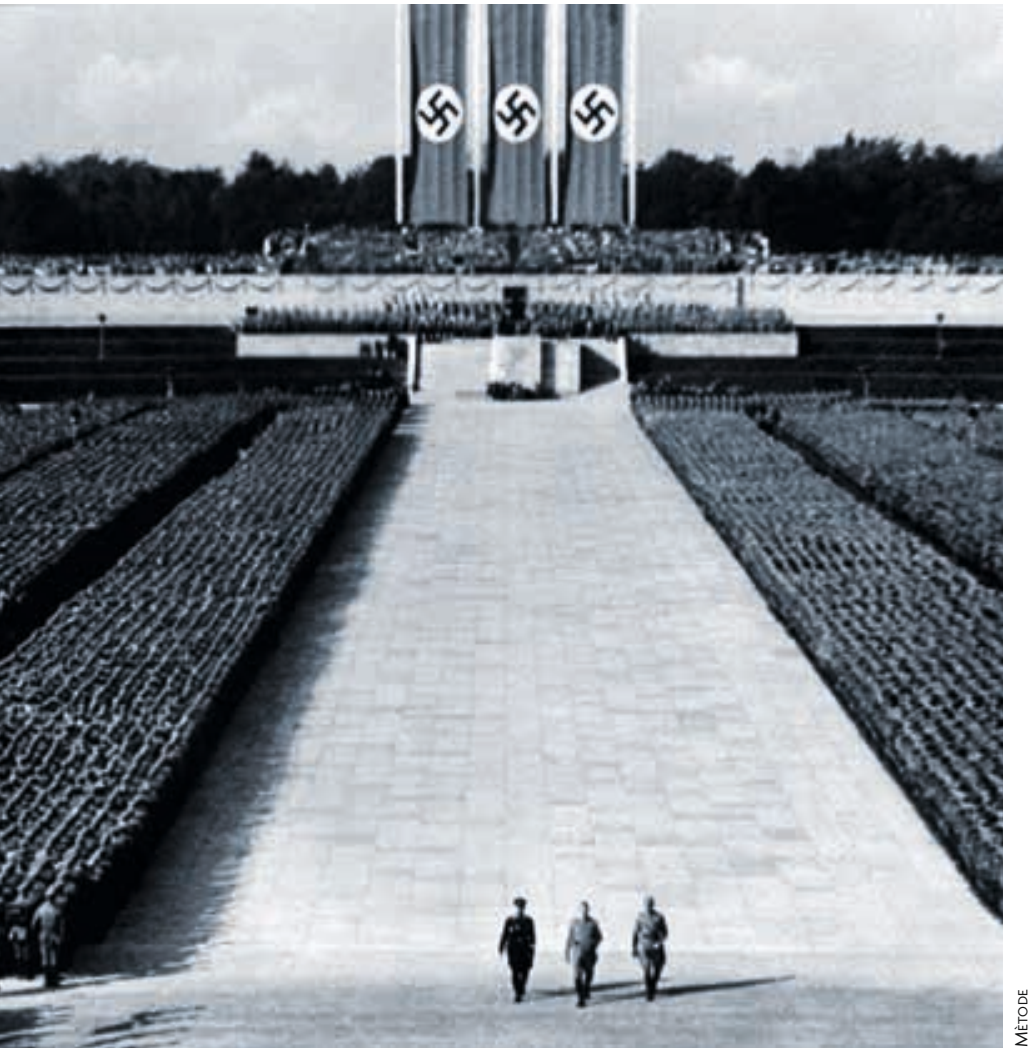

Biblical literalists, creationists and intelligent design theorists, tried first to show that evolutionary biology is not good science. That failed, so then they turned more philosophical, arguing that it fails methodologically and metaphysically. That attack too came to naught. So now they are trying to tar it with the charge of immorality, basing their case on the supposed historical fact that nineteenth-century evolutionary theory led straight to the philosophy underlying the Third Reich. The picture shows a still from Triumph of the will, a propaganda Nazi film directed by Leni Riefenstahl, 1935.

All claims that the State has an intrinsically higher value than the individual are false. They turn out, on closer scrutiny, to be rationalizations or myths aimed at securing greater power or privilege for a limited group which controls the machinery of the State. On the other hand the individual is meaningless in isolation, and the possibilities of development and self-realization open to him are conditioned and limited by the nature of the social organization. The individual thus has duties and responsibilities as well as rights and privileges, or if you prefer it, finds certain outlets and satisfactions (such as devotion to a cause, or participation in a joint enterprise) only in relation to the type of society in which he lives.

(Huxley, 1934, pp. 138-139)

Huxley was insistent that this all came directly from a reading of evolutionary biology. Which may or may not be true, but which certainly flags us to the dangers and pitfalls of thinking that there is an easy and clear connection between science and ideology. There are such connections, but they are complex and not necessarily fully apparent to those who are drawing them. That is what makes the topic important, interesting, and challenging.

\section{REFERENCES}

Bannister, R. (1979). Social Darwinism: Science and myth in AngloAmerican social thought. Philadelphia: Temple University Press.

Darwin, C. (1859). On the origin of species by means of natural selection, or the preservation of favoured races in the struggle for life. London: John Murray.

Darwin, C. (1871). The descent of man, and selection in relation to sex. London: John Murray.

Darwin, C. (1985). The correspondence of Charles Darwin. Cambridge: Cambridge University Press.

Gould, S. J. (1981). The mismeasure of man. New York: Norton.

Harrington, A. (1999). Reenchanted science: Holism in German culture from Wilhelm II to Hitler. Princeton, NJ: Princeton University Press. Hitler, A. (1925). Mein Kampf. London: Secker and Warburg.

Huxley, J. S. (1934). If I were dictator. New York and London: Harper and Brothers.

Johnson, P. E. (1995). Reason in the balance: The case against naturalism in science, law and education. Downers Grove, IL: InterVarsity Press.

LeVay, S. (2010). Gay, straight, and the reason why: The science of sexual orientation. Oxford: Oxford University Press.

Lewontin, R. C. (1991). Biology as ideology: The doctrine of DNA. Toronto: Anansi.

Plantinga, A. (2011). Where the conflict really lies: Science, religion, and naturalism. New York: Oxford University Press.

Popper, K. R. (1972). Objective knowledge. Oxford: Oxford University Press.

Richards, R. J. (1987). Darwin and the emergence of evolutionary theories of mind and behavior. Chicago: University of Chicago Press.

Richards, R. J. (2013). Was Hitler a Darwinian? Disputed questions in the history of evolutionary theory. Chicago: University of Chicago Press.

Richards, R. J., \& Ruse, M. (2016). Debating Darwin. Chicago: University of Chicago Press.

Ruse, M. (2016). Darwinism as religion: What literature tells us about evolution. Oxford: Oxford University Press.

Segerstrale, U. (1986). Colleagues in conflict: An in vitro analysis of the sociobiology debate. Biology and Philosophy, 1,53-88. doi: 10.1007/ BF00127089

Spencer, H. (1851). Social statics; or the conditions essential to human happiness specified and the first of them developed. London: J. Chapman. Spencer, H. (1857). Progress: Its law and cause. Westminster Review, LXVII, 244-267.

Spencer, H. (1879). The data of ethics. London: Williams and Norgate.

Wallace, A. R. (1900). Studies: Scientific and social. London: Macmillan.

Wallace, A. R. (1905). My life: A record of events and opinions. London: Chapman and Hall

Weikart, R. (2004). From Darwin to Hitler: Evolutionary ethics, eugenics, and racism in Germany. New York: Palgrave Macmillan.

Whitcomb, J. C., \& Morris, H. M. (1961). The Genesis flood: The biblical record and its scientific implications. Philadelphia: Presbyterian and Reformed Publishing Company.

Wilson, E. O. (1975). Sociobiology: The new synthesis. Cambridge, MA: Harvard University Press.

Wilson, E. O. (1978). On human nature. Cambridge, MA: Harvard University Press.

Young, R. M. (1985). Darwin's metaphor: Nature's place in Victorian culture. Cambridge, MA: Cambridge University Press.

Michael Ruse. Lucyle T. Werkmeister Professor of Philosophy and director of History and Philosophy of Science Program at the Florida State University (USA). He is the author of many books including Taking Darwin seriously: A naturalistic approach to philosophy (1986), The philosophy of biology (1988) and Charles Darwin (2008). He founded the journal Biology and Philosophy. 